\title{
A study of contaminated land in São Paulo city, Brazil and mainly adopted remediation process face a deficient database
}

\author{
Juliana dos Santos Lino'1, Afonso Rodrigues de Aquino ${ }^{1}$ \\ ${ }^{1}$ Instituto de Pesquisas Energéticas e Nucleares, IPEN-CNEN/SP, Universidade de São Paulo \\ Professor Lineu Prestes Av, 2242 - Cidade Universitária - CEP: 05508-000, São Paulo, SP, Brazil \\ jslino@usp.br; araquino@usp.br
}

\begin{abstract}
Since emblematic environment contaminated cases, as Love Canal in United States was found out, the discussion regarding contaminated land are common in scientific community, covering subjects as urban planning, public health and availability of natural resources. Concerns with environment contamination are also relevance because can impact the progress to The Sustainable Development Goals, a global blueprint to develop a sustainable future. Contaminated land refers to areas that have been contaminated by industrial activities, irregular waste disposal or toxic substances. Lack of management of these areas can harm the development of sustainable future, for the cities and citizens. Therefore, the existence and availability of data on the areas that are contaminated is necessary to create better urban planning. In Brazil there are not federal programs to deal with contaminated sites and a federal database regarding this information is absent. However, São Paulo State has been a pioneer in management of contaminated areas in Brazil, developing laws and regulations, since 1999. The aim of this research is to present data regarding contaminated areas in municipality of São Paulo, in five districts, providing information about the scattering of contaminated areas across the districts, the main polluting activity, also observing aspects as revitalization and clean-up process to realize if the remediation process is occurring in the city. This study is a qualitative exploratory research, with information obtained from secondary sources. The results indicated that the main polluting activity is gas station, the process of revitalization and clean-up is happening in all districts evaluated, also showed that environment compartment more affected is Groundwater.
\end{abstract}

Keywords: Contaminated Land, Brownfields, Urban Land Use, Sustainable development.

(C) Copyright 2019 Authors - This is an Open Access article published under the Creative Commons Attribution
License terms (http://creativecommons.org/licenses/by/3.0). Unrestricted use, distribution, and reproduction in any medium are permitted, provided the original work is properly cited.

\section{Introduction}

In 2016, an estimated 54.5 per cent of the world's population lived in urban areas. By 2030, urban areas are projected to house 60 per cent of people globally and one in every three people will live in cities with at least half a million inhabitants. According to United Nations, in 2016, 45 cities had population between 5 and 10 million inhabitants. Cities with more than 10 million inhabitants are often termed "megacities"[1]. Considering the cities' rise it is necessary the understanding the key trends in urbanization likely to unfold over the coming years is crucial to develop sustainable cities.

Ensure a sustainable future to the next generations is a global concern, it was approached by the first time in a Report termed Our Common Future [2]. Following these aim The United Nations Conference on Sustainable Development took place in Rio de Janeiro, Brazil in 2012. It resulted in a focused political outcome document which contains clear and practical measures for implementing sustainable development. Member States decided to launch a process to develop a set of Sustainable Development Goals (SDGs), which built upon the Millennium Development Goals [3]. The next meeting was United Nations Sustainable Development Summit 2015, in New York when was announced the SDGs, an action plan for "peace and prosperity for people and the planet, now and into the future", a call for action to change our world [4]. Goals to deal with the most 
urgent environmental, economics and politicians challenges, that the world faces.

The Agenda is formed by 17 goals:

- $\quad$ "Goal 1 end poverty in all its forms everywhere;

- Goal 2 end hunger achieve food security and improved nutrition and promote sustainable agriculture;

- Goal 3 ensure healthy lives and promote wellbeing for all at all ages;

- Goal 4 ensure inclusive and equitable quality education and promote lifelong learning opportunities for all;

- Goal 5 achieve gender equality and empower all women and girls;

- Goal 6 ensure availability and sustainable management of water and sanitation for all;

- Goal 7 ensure access to affordable, reliable, sustainable and modern energy for all;

- Goal 8, promote sustained, inclusive and sustainable economic growth, full and productive employment and decent work for all;

- Goal 9, build resilient infrastructure, promote inclusive and sustainable industrialization and foster innovation;

- Goal 10 reduce inequality within and among countries;

- Goal 11 make cities and human settlements inclusive, safe, resilient and sustainable;

- Goal 12 ensure sustainable consumption and production patterns;

- Goal 13 take urgent action to combat climate change and its impacts;

- Goal 14, conserve and sustainably use the oceans, seas and marine resources for sustainable development;

- Goal 15, protect, restore and promote sustainable use of terrestrial ecosystems, sustainably manage forests, combat desertification, and halt and reverse land degradation and halt biodiversity loss;

- Goal 16, promote peaceful and inclusive societies for sustainable development, provide access to justice for all and build effective, accountable and inclusive institutions at all levels;

- Goal 17, strengthen the means of implementation and revitalize the Global Partnership for Sustainable Development" [4].

The Goals and targets will stimulate action over the next 15 years in areas of critical importance for humanity and the planet.
Over the years, the anthropic activities have caused degradation and environmental contamination, mainly in cities whose history has been marked by the development of industry. United States had an emblematic case in 70' termed as Love Canal. The Love Canal is a chemical dump site in Niagara Falls, New York. Although originally designed to be a water power canal, the uncompleted 16 acre canal served instead as a chemical and municipal dump site from the 1920's until 1953, when it was roofed with earth. During the mid $1950 \mathrm{~s}$ residential development increased in the immediate neighborhood of the landfill and a school was built directly abutting the landfill. In administrative orders issued on June 20, 1978 and August 2, 1978 the New York State Commissioner of Health determined than the site constitutes an extremely serious threat and danger to the health, safety, and welfare [5].

This case causes relevant changes in Americans laws, to management contaminated land, awareness of the relevance of contaminated areas.

According to United Stations Environmental Protection Agency (USEPA) contaminated land is a result from a diversity of intended, accidental, or naturally occurring activities and proceedings such as manufacturing, mineral extraction, abandonment of mines, national defence activities, waste disposal, accidental spills, illegal dumping, leaking underground storage tanks, hurricanes, floods, pesticide use, and fertilizer application. These areas can present of varying size and significance in sceneries ranging from abandoned buildings in inner cities to large areas contaminated with toxic materials from past use. Contaminated lands include sites contaminated by inappropriate handling or disposal of toxic and hazardous materials and wastes, also sites where toxic materials may have been deposited as a result of natural disasters or acts of terror [6].

Brownfields, for instance, are a type of contaminated land. The term brownfield is the antagonism to greenfield The definition is "real property where expansion, redevelopment, or reuse may be complicated by the presence or potential presence of a hazardous substance, pollutant, or contaminant" [7].

Therefore, contaminated land affects the soil quality and can also implicate the groundwater quality, according to the contaminant behaviour. Thus, there are a strong relationship between the contaminated land question and SDGs. Goal 6 aims to tackle challenges related to drinking water, sanitation and hygiene for populations, as well as to water-related ecosystems. 
Without quality, sustainable water resources and progress in many other areas across the SDGs, health for instance, will also be diminished [8]. Goal 11, sustainable cities, considers than with the number of people living within cities projected to rise to 5 billion people by 2030, it's imperative that efficient urban planning and management practices are in place to deal with urbanization. Many challenges exist to maintaining cities in a way that endures to create jobs and prosperity without straining land and resources. One of the targets of this goal is "support positive economic, social and environmental links between urban, peri-urban and rural areas by strengthening national and regional development planning"[9].

Regarding the goal 15, the aim is protected and restored ecosystems and the biodiversity. Healthy ecosystems likewise produce multiple benefits for communities that rely on them. The focus is on preserving and sustainably using the earth's terrestrial species and ecosystems [8]. Contaminated areas can impact the ecosystem and the biodiversity too.

Discussions related to the identification of contaminated land, ways to manage them and brownfield revitalization are contemporary themes and permeate the fields of environment, urban development, and public health.

The Brazilian Federal Constitution establishes that "the protection of the environment and fighting pollution in any of its forms" is a common competence of the Union, the States, the Federal District and the Municipalities, according to article 24, I and IV. Therefore, the competence to legislate upon the natural resources and soil protection, environment protection and pollution control is concurrent to the Union, the States and the Federal District [10][11].

Brazil also has an environment contamination emblematic case known as Cidade dos Meninos. In 1989, the Rio de Janeiro State environmental agency (FEEMA), after a preliminary survey on the site Cidade dos Meninos, situated at the municipality of Duque de Caxias, metropolitan region of Rio de Janeiro, collected and disposed in a safety area tons of a pesticide that was spread in and around the ruins of an old Hexachlorocyclohexane (HCH) factory [12]. However, despite of the disaster in Rio de Janeiro, Brazil do not have a federal program to accomplish contaminated land remediation, as in United States. In fact, there is no federal database regarding contaminated areas in Brazil. In 2016, Institute for Technological Research (IPT), a public research institute linked to the Secretariat for
Economic Development, Science, Technology and Innovation of the State of São Paulo published an inventory of contaminated areas in Brazil, based on consultations with state environmental agencies and environmental consulting firms [13]. Table 1, below, shows the numbers found by IPT, about contaminated land in 17 states.

Table 1. Contaminated land in Brazil 2016.

\begin{tabular}{|l|c|}
\hline State & Contaminated land[13] \\
\hline Pará & 2 \\
\hline Amazonas & 1 \\
\hline Pernambuco & 5 \\
\hline Piauí & 5 \\
\hline Sergipe & 9 \\
\hline Paraíba & 23 \\
\hline Bahia & 1 \\
\hline Tocantins & 1 \\
\hline Distrito Federal & 5 \\
\hline Mato Grosso & 1 \\
\hline Espírito Santo & 271 \\
\hline Rio de Janeiro & 578 \\
\hline Minas Gerais & 5351 \\
\hline São Paulo & 4 \\
\hline Paraná & 10 \\
\hline Santa Catarina & 18 \\
\hline Rio Grande do Sul & \\
\hline
\end{tabular}

It is important to realise that Brazil has 27 federative units, 26 states and one federal district, the country's capital.

As for contaminated land, Brazil only has a law with criteria and guiding values of soil quality about the presence of chemical substances and guidelines for the process of managing contaminated areas [14]. According to this law contaminated land is defined as places where there are the presence of chemical substances above the reference values and due to anthropic activities which limit the use of this environmental resource either for current or future use [14], [15].

Regarding to guiding values of soil quality, these are defined in accordance with international standards and considering two tools: the exposure scenarios and Human Health Risk Assessment. The exposure scenarios are Rural, Residential and Industry, each one has different reference values. The reference values are divided in three sorts: reference quality, is the concentration of a substance that defines the natural quality of the soil; prevention, is the limit concentration of a substance in the soil, such that soil is capable of sustaining its main functions; investigation, is the 
concentration of a given substance in soil or groundwater above which there are potential direct or indirect risks to human health [14] The law also allows to States determine their own reference values. The table 2 indicates some substances and their investigation values in soil.

Table 2. Investigation value.

\begin{tabular}{|l|l|l|l|}
\hline \multirow{2}{*}{ Substance } & \multicolumn{3}{|l|}{ Investigation Value (mg kg-1)[14] } \\
\cline { 2 - 4 } & Rural & Residential & Industry \\
\hline Arsenic & 35 & 55 & 150 \\
\hline Lead & 180 & 300 & 900 \\
\hline Mercury & 12 & 36 & 70 \\
\hline Cadmium & 3 & 8 & 20 \\
\hline Benzene & 0,06 & 0,08 & 0,15 \\
\hline Styrene & 15 & 35 & 80 \\
\hline Ethylbenzene & 35 & 40 & 95 \\
\hline Toluene & 30 & 30 & 75 \\
\hline Xylenes & 25 & 30 & 70 \\
\hline Phenanthrene & 15 & 40 & 95 \\
\hline Naphthalene & 30 & 60 & 90 \\
\hline 1,1-Dichloroethane & 8,5 & 20 & 25 \\
\hline Vinyl chloride & 0,005 & 0,003 & 0,008 \\
\hline $\begin{array}{l}\text { Pentachlorophenol } \\
\text { (PCP) }\end{array}$ & 0,35 & 1,3 & 3 \\
\hline DDT & 0,55 & 2 & 5 \\
\hline HCH-gamma (Lindane) & 0,02 & 0,07 & 1,5 \\
\hline
\end{tabular}

Once the reference values were established, if an area has substances above these values, the process of managing contaminated areas is initiated, according to the federal law. The process is constituted of a series of environmental investigations and analyses, measures of intervention and remediation of the area, focusing on diminishing the human health risks for the intended future use. All the field analyzes, developed by consultancies and certified laboratories during a process of managing contaminated areas should be submitted to state environmental agency.

Even though the lack of a federal public policy to treat contaminated land and official information, São Paulo, through Environmental Company of the State of São Paulo (CETESB), is the pioneering State in Brazil that has approved specific rules to deal with the problem of contaminated areas and is already enforcing these rules. São Paulo is in charge of the environmental management of contaminated sites and the control of pollution. Since the beginning of the 90' due to the German know-how regarding this subject, a technical cooperation was established, which encompasses both technical and financial support. This cooperation permitted the capacitate of the CETESB for the management of contaminated sites [16]. Inside this project, some publications was done, as a Contaminated Area Management Guideline [17] and a Guideline to Revitalize contaminated areas [18].

São Paulo State has a specific law to contaminated land, providing guidelines and procedures for soil quality protection and management of contaminated areas [19]. Also, there are a decree to regulate actions, as the CETESB definition as the agency responsible for planning and managing the process of identifying contaminated areas in the State of São Paulo. Another relevant regulations is regarding the procedure to reused contaminated areas [20].

Despite São Paulo State holds a specific law to contaminated land, there is not state or municipalities programs to treat brownfields and reused these places. In 2017 São Paulo State had 5942 contaminated areas [21]. The master plan of São Paulo city, for instance, only foresees actions aimed at the conservation and reforestation of degraded public areas, as parks, springs and areas of environmental protection, [22]. Therefore, generally a contaminated area is identified and starts the management process based on the need to land reuse, as old industrial areas [23] and in processes involving getting environmental licenses.

The city of São Paulo is located at the southeast region of Brazil, in state of São Paulo. It has an area of $1,521.11 \mathrm{~km}^{2}$ and a population of approximately $12,106,920$ inhabitants with a population density of $7,398.26 \mathrm{hab} / \mathrm{km}^{2}$ [24]. Of the 31 megacities in the world, in 2016, 24 megacities are located less developed regions or in the "global south". In this ranking, the metropolitan region of São Paulo occupies the fifth position[1].

Over the years, different studies were done on environmental contamination and reuse of contaminated areas in the city of São Paulo. In 2010, a study focus in measuring the metals presence in playground soils was developed by Figueiredo, Tocchini and Santos, the results obtained concentration levels higher than the reference values for soils in São Paulo [25]. In 2016 Silva approached the reutilization process of 03 public sites [23]. Salinas evolves a study in 2016 focuses on an area inside the Urban Operation of Tamanduateí District, which conflicts with the proposals brought by the Urban Operation Law since it does not set guidelines for how to deal with the issue of contamination [26]. 
Barbosa, Bertolo and Hirata developing a huge research about the management of contaminated areas with multiple sources of contamination, often termed as megasites. This study identifies the one of the main reasons that hamper the proper management of urban environmental problems is a lack of a unified system where all data can be easily integrated into regional studies [27].

Currently São Paulo city has 2,148 contaminated areas. In 448 places, occurred or is planned the reuse of contaminated areas[28], this means a change of use trend in the occupation of deactivated areas, considering that these areas are, in the majority, destined to the construction of real estate projects. However, how the contamination and revitalization process are distributed in the city is not so evident.

The aim of this research is to present data regarding the reality across contaminated areas in municipality of São Paulo, specifically in five districts located in different regions, providing information about the scattering of contaminated areas, the main polluting activity, also observing aspects as revitalization and clean-up process to realize if the remediation process is occurring in the city. Data regarding concentration of inhabitant and price per meter as well were collected because they provide relevant information to understand profile zone and the demand by area. Due to the lack of knowledge of the values found in the field analysis of the contaminated areas, this work also aims to raise awareness of the need of the environmental agencies to organize and make available the values.

\section{Methodology}

This study is a qualitative exploratory research, with information obtained from secondary sources. The territorial unit used was district, because São Paulo is a huge city, and its districts have dissimilar historical sorts of use. Were chosen five districts by São Paulo city to analyse the contaminated areas and identify the percentage of revitalization and clean-up process, using public data of the Report of Contaminated and Remediated areas in São Paulo State [21], published by Environmental Agency of São Paulo State (Companhia Ambiental do Estado de São Paulo-CETESB) which yearly provides a list with the whole investigated areas. The list contains summarize information about contaminated site, as location, type of chemical substance and information regarding the classification, which is based at the step of the contaminated area management process, e.g. under investigation, during the remediate process or remediated. Every chosen district are located in different region of the São Paulo city: Santo Amaro (south region), Butantã (west side), Casa Verde (north region), Aricanduva (east side) and Cambuci (district central). The number of inhabitants per district was obtained by the Statistical Portal of the State of São Paulo, maintained by the government of the state of São Paulo[29]. Regarding the data of the total area of each district, the information of the prefecture of the city of São Paulo was used[30]. Concerning the average price of the square meter in the selected districts, the values were extracted from the FIPE ZAP, an Index of Prices of Real Estate Announced, which is an indicator with national coverage, and accompanies the sale and lease prices of real estate in Brazil. The index is calculated by the Foundation for Economic Research (Fundação Instituto de Pesquisas Econômicas- Fipe) based on data published in a portal of Real Estate and other Internet sources [31]. About zoning law applied for studied places were used a framework with georeferencing data by prefecture on São Paulo[32]. Ultimately, to elaborate the images of the districts and the contaminated areas, the Paulista Environmental System, a tool with georeferenced data provided by the São Paulo State Government was used[33].

\section{Results and discussion}

The table 3 shows the obtained data by district, as well the size of each districts in kilometres, number of inhabitants, the price of the square meter, total of contaminated areas, total of cleaned-up areas, the percentage of clean-up for districts and the number of the reutilized places or in reutilized process. 
Table 3. Data of districts 1.

\begin{tabular}{|c|c|c|c|c|c|c|}
\hline District & Aricanduva & Butantã & Cambuci & Casa Verde & $\begin{array}{c}\text { Santo } \\
\text { Amaro } \\
\end{array}$ & Total \\
\hline $\begin{array}{c}\text { Inhabitants } \\
{[29]}\end{array}$ & 86,501 & 53,970 & 40,049 & 86,009 & 74.139 & 340,668 \\
\hline $\begin{array}{c}\text { Area in } \mathrm{Km}^{2} \\
{[10]}\end{array}$ & 6.60 & 12.50 & 3.90 & 7.10 & 15.60 & 45.70 \\
\hline $\begin{array}{c}\text { Price of } \mathbf{~ m}^{2} \\
{[31]}\end{array}$ & $\mathrm{R} \$ 4,718.00$ & $\mathrm{R} \$ 5,965.00$ & $\mathrm{R} \$ 6,878.00$ & $R \$ 6,927.00$ & $\mathrm{R} \$ 8,242.00$ & $\begin{array}{c}\mathrm{R} \$ 6.546,00 \\
\text { (average) }\end{array}$ \\
\hline $\begin{array}{c}\text { Contaminated } \\
\text { areas }[21]\end{array}$ & 16 & 26 & 28 & 17 & 79 & 166 \\
\hline $\begin{array}{c}\text { Clean-up } \\
\text { areas[21] }\end{array}$ & 4 & 7 & 6 & 4 & 26 & 47 \\
\hline $\begin{array}{l}\text { Percentage of } \\
\text { clean-up } \\
\text { areas }\end{array}$ & $25 \%$ & $26.92 \%$ & $21.43 \%$ & $23,53 \%$ & $32.50 \%$ & $28,14 \%$ \\
\hline $\begin{array}{c}\text { Reused } \\
\text { places[21] }\end{array}$ & 4 & 3 & 11 & 3 & 34 & 55 \\
\hline
\end{tabular}

According to the table 3 , it is possible to identify that contaminated land revitalization process is happening in all analysed districts. However, Santo Amaro presents the biggest percentage of clean-up areas, which is where the price of the square meter is higher. Areas located in regions of high land value are enjoyed by people with greater purchasing power and therefore greater power of political pressure. This fact was observed in other study [34].

Information in last row of the table 3, Reused Places refers to areas with an occupation different of the activity that caused the contamination. In some cases, are not completed the remediation process, but exist a kind of occupation, like parking, offices or residences.

Every year when the environment agency of São Paulo (CETESTB) publishes the "Report of Contaminated and Remediated Areas" containing state information, it is also published summarize data regarding the main polluting activities which were originated the contaminated land in whole state, as well highlighting data of metropolitan region of São Paulo and other regions in the state, individually. As reported by the official document the most polluting activity in São Paulo city is gas station. There are 1,579 contaminated areas, which corresponds to $73.5 \%$ of the total contaminated land in the whole city, that is 2148 areas in 2017 [28]. These results were predictable because the laws and regulations to identify and to manager these places are older and more consolidated [35].
Figure 1 presents information about polluting activities focusing on the five analysed districts.

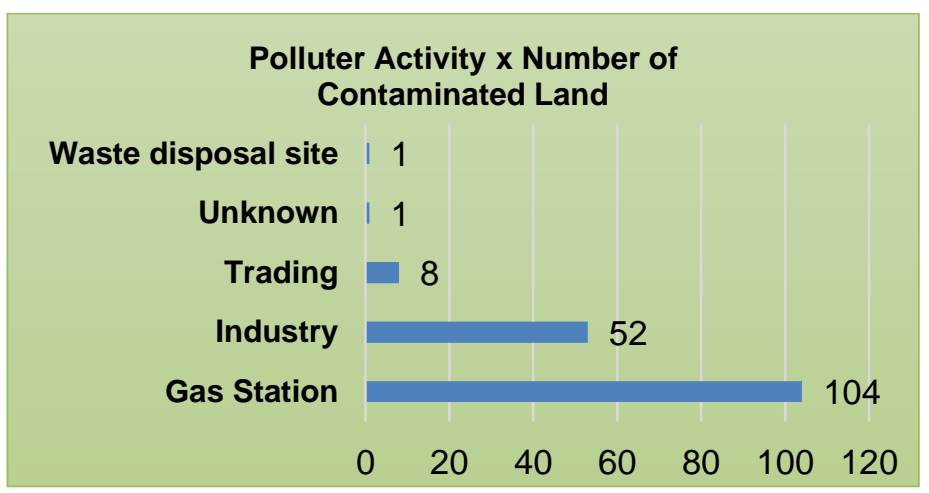

Figure 1. Polluter Activity.

As is possible to realise in Figure 1, there is a difference between the found values contaminated land for gas station in the analysed districts and with data of the whole city. The result for the gas station, in the five districts, was $62 \%$.

Regarding the main environmental compartments affected in studied places, Figure 2 below, shows the results found, which was groundwater. This is an issue significant because the access to an essential resource, as water could be impacted [36][37][38][39][40]. The costs of the treatment can also increase.

In the State of São Paulo, currently, approximately $80 \%$ of the municipalities are supplied entirely or partially by groundwater [41]. The existence of many 
contaminated areas can impair the use of groundwater to supply public even though in many cases the contamination does not reach deep aquifers [42], even so it is still a relevant question to concern.

It was observed reutilization in 55 areas according to table 3 . The main type of reuse observed in the places studied was offices and trading (commercial areas) followed by residential use, as evidenced in Figure 3. An

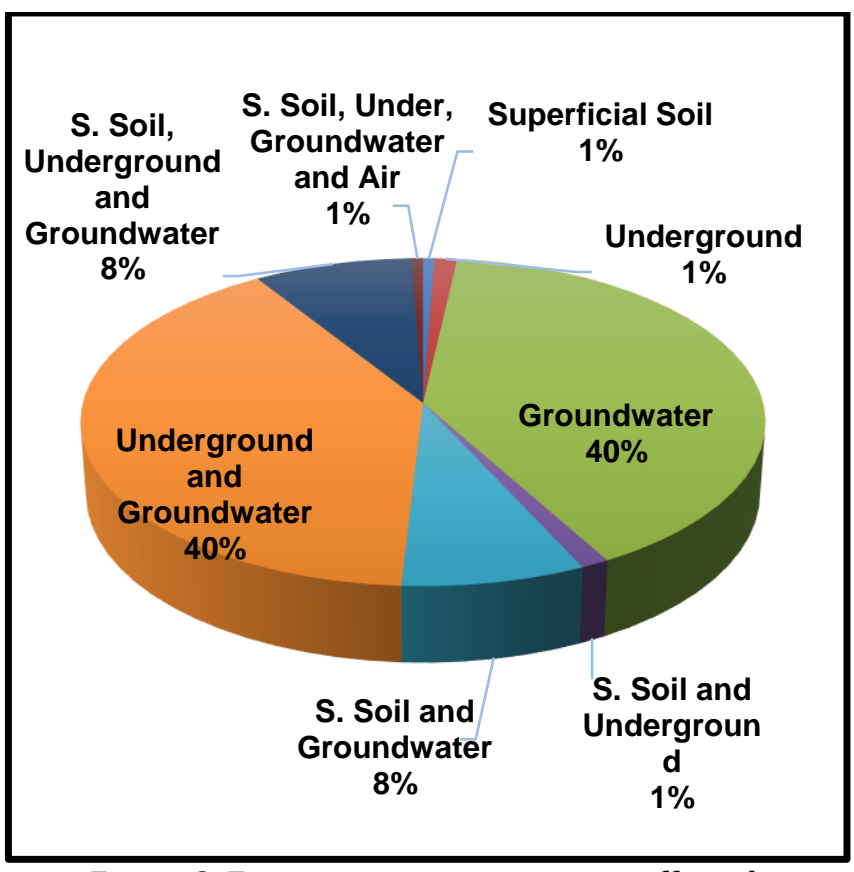

Figure 2. Environment compartment affected.

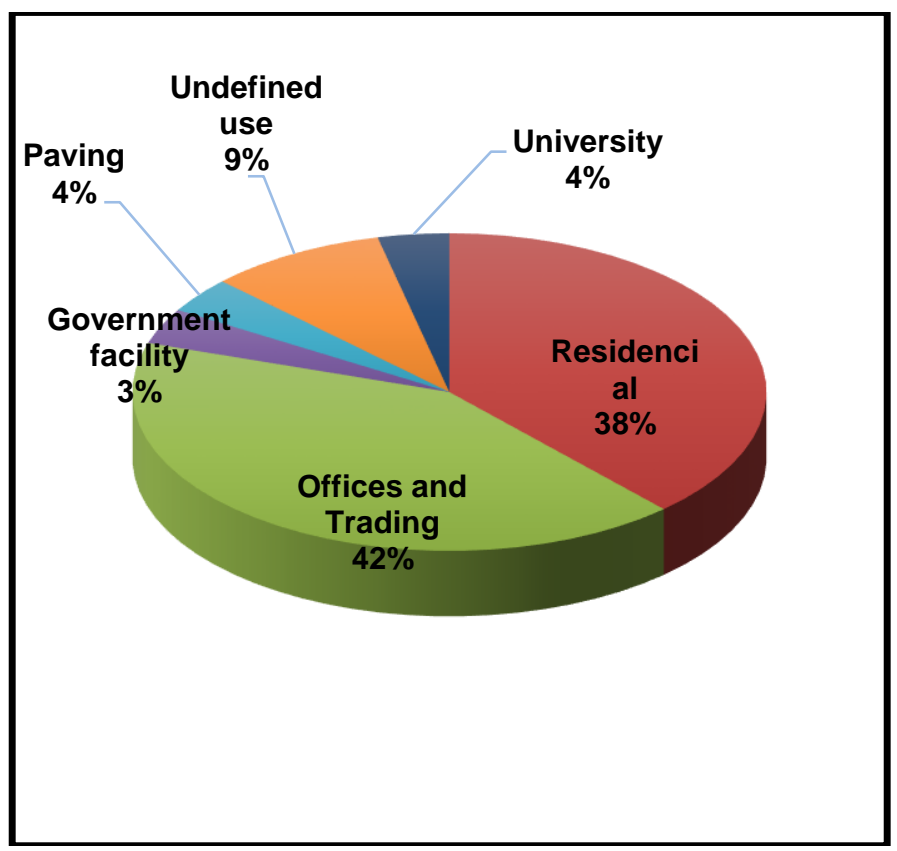

Figure 3. Type of reutilization. education use also was identified and it means than an educational institution (University) bought a place which was classified as contaminated land. The Figure 4, is about the number of areas classified as places with confirmed risk to human health, considering the districts separately.

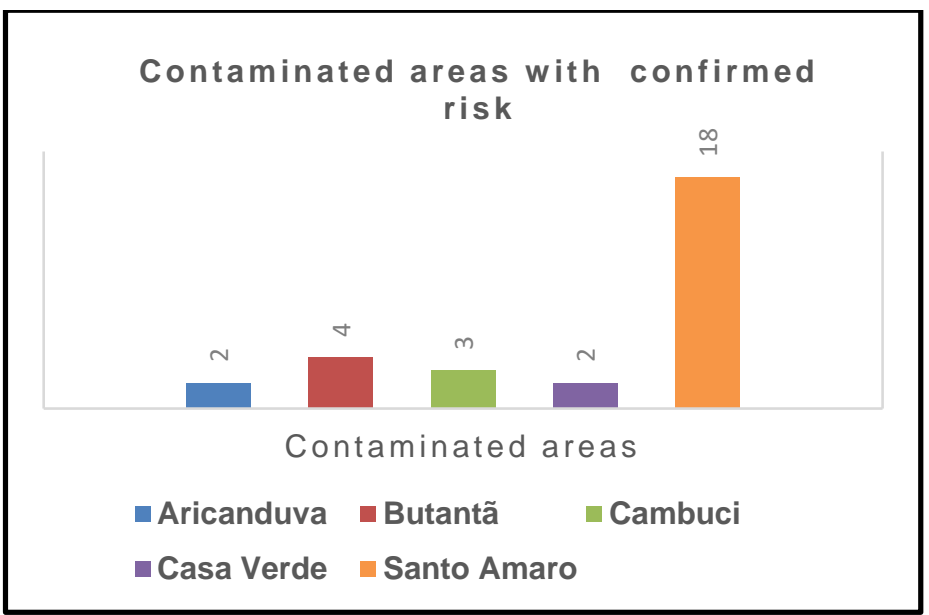

Figure 4. Contaminated sites with confirmed risk.

Figure 4 evince the district of Santo Amaro has the most number of contaminated sites with confirmed risk. This value means $22.5 \%$ places with a confirmed risk of the total contaminated sites identified in the district according the Table 3, and this result is exceedingly relevant from public health ambit. Figure 5 below presents the results regarding the groups of chemical contaminants found. Information about concentration and the type of specific chemical substance it is not available on the Report of Contaminated and Remediated areas in São Paulo State. CETESB has an information system for potential sources of pollution which is used to register contaminated sites, however it contains only cadastral and licensing information. All the data related to environmental studies, analysis and historic evolution of the sites are stored in physical files, electronic PDF files or spreadsheets. Each of these resources is separated in individual records, making the information fragmented and inaccessible [27].

Figure 6 is about the remediation process to cleanup the site and presents the main types. Finally, the Figure 7 is the distribution by polluter activity per each district. 


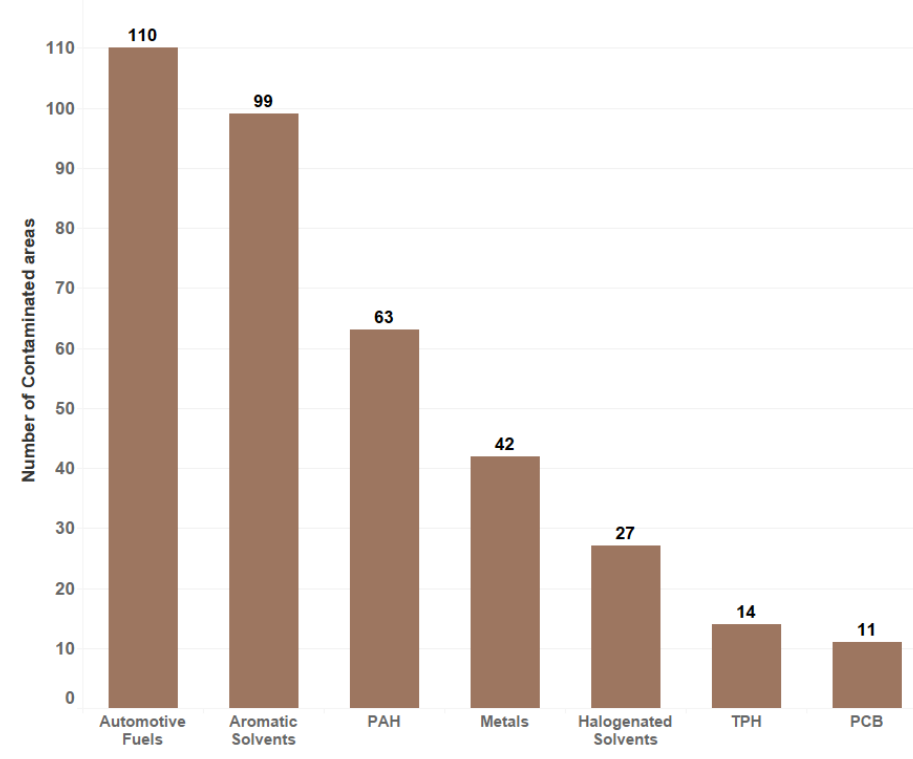

Figure 5. Contaminants group.

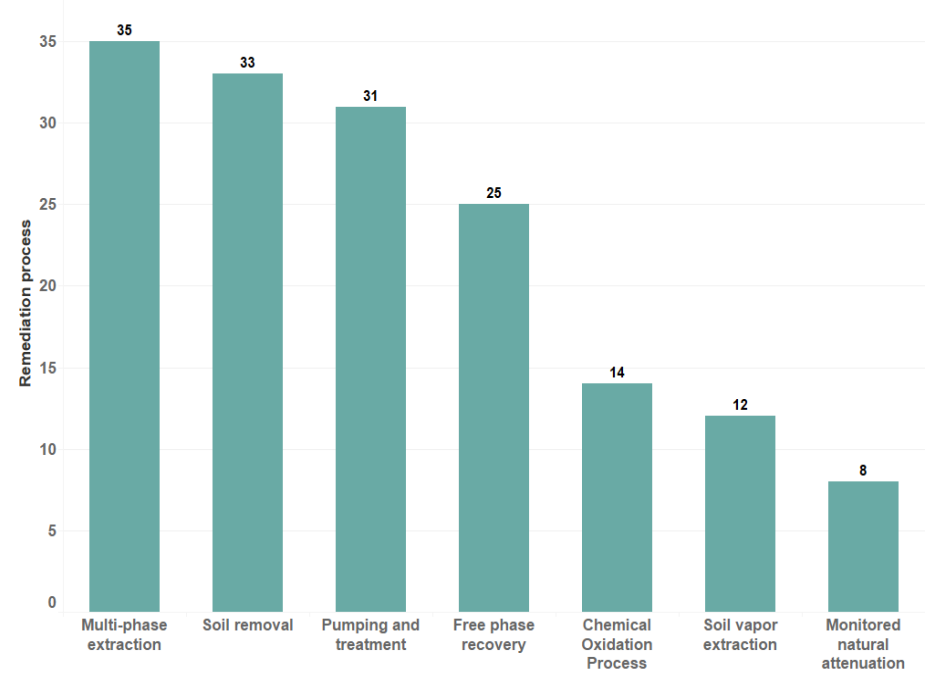

Figure 6. Kind of remediation process.

Polluter Activity

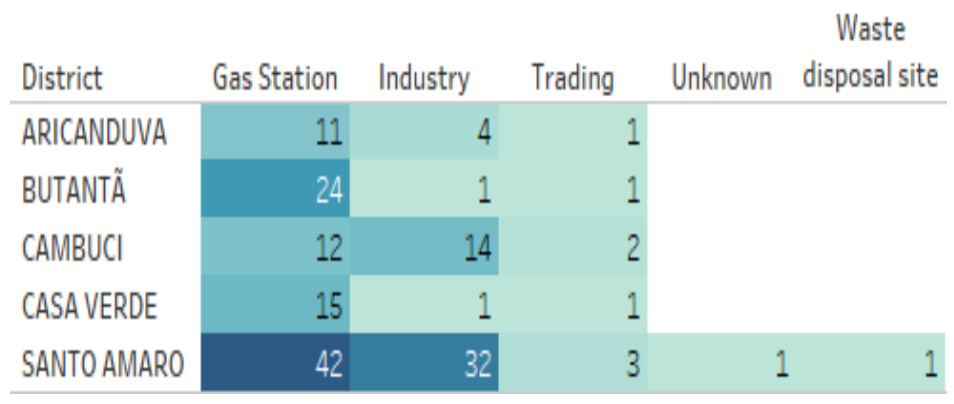

Figure 7. Polluter activity per district.

According to the Figure 5 the main contaminant group is Automotive Fuels, following by Aromatic
Solvents and PAH, all substances which can be found in gas station sites, which was the principal polluter activity on the analysed districts. It is important to say than in a lot of sites there are two or more contaminants group in the same site. In Figure 6, the principal kind of remediation process is multi-phase extraction following by soil removal. The Figure 7 compares the polluting activities which were developed by each district. It is possible to observe than in Santo Amaro there are the most concentration of industrial activities, with 32 sites.

Multi-phase extraction, the remediation process more adopted in analysed areas, uses a vacuum system, which can also be joint with a downhole pump, to remove several combinations of contaminated groundwater, separate-phase petroleum product, and vapours from the subsurface. The system lowers the water table around the well, exposing more of the formation. Contaminants in the newly exposed vadose zone are then accessible to vapor extraction. Once above ground, the extracted vapours or liquid-phase organics and ground water are separated and treated [43]. Soil removal or excavation of contaminated soil from a site involves digging it up for "ex situ" (above-ground) treatment or for disposal in a landfill [44]. In studied areas, when soil removal was chosen, this soil was disposal in a landfill.

The basic components of a Pumping and treatment system include ground water extraction, above-ground treatment, disposal of the treated water, ground water monitoring in the subsurface, and process monitoring in the treatment plant [45].

Free phase recovery is related free phase, which is a type of contaminant behaviour. The Free phase consists of hydrocarbons that are not water miscible, less dense than water (LNAPL) and therefore float on top of the free aquifer. It may be thicker where the water table shows few oscillations, in low permeable areas and according to the volume of product spilled. Multi-phase extraction can be used as a process in order to recovery the free phase [46].

Chemical oxidation uses chemicals to help change harmful contaminants into less toxic ones. It is usually described as "in situ process" because it is conducted in place, without having to excavate soil or pump out groundwater for aboveground clean-up. In situ chemical oxidation, or "ISCO," can be applied to treat many types of contaminants like fuels, solvents, and pesticides [47].

Soil vapor extraction (SVE) is an in situ unsaturated zone soil remediation technology in which a vacuum is applied to the soil to induce the controlled 
flow of air and eliminate volatile and some semi volatile contaminants from the soil. The gas leaving the soil may be treated to recuperate or destroy the contaminants, depending on local and state air discharge regulations [48]. Natural attenuation depends on the natural processes to clean up or attenuate pollution in soil and groundwater. However, the right conditions must exist underground to clean sites properly. If not, clean-up will not be quick sufficient or complete enough. It is possible to monitor or test these conditions to make sure natural attenuation is working. This is termed monitored natural attenuation or MNA [49].

Figure 8, following presents information concerning reused sites versus type of polluting activity, the past use.

\section{Polluter Activity}

\begin{tabular}{|c|c|c|c|c|c|}
\hline Reused & $\begin{array}{l}\text { Gas } \\
\text { Station }\end{array}$ & Industry & Trading & Unknown & $\begin{array}{c}\text { Waste } \\
\text { disposal } \\
\text { site }\end{array}$ \\
\hline no & 93 & 13 & 4 & & 1 \\
\hline yes & 11 & 39 & 4 & 1 & \\
\hline
\end{tabular}

Figure 8. Reused sites versus type of past Polluter activity.

In Figure 8 is possible to note than Industry is the main type in reused areas.

\begin{tabular}{ll|rr} 
& & \multicolumn{2}{|c}{ Classification } \\
Reused & Polluter Activity & $\begin{array}{l}\text { Contaminated sites } \\
\text { with confirmed risk }\end{array}$ & $\begin{array}{c}\text { remediated for } \\
\text { declared use }\end{array}$ \\
\hline no & Gas Station & 14 & 19 \\
& Industry & 5 & 1 \\
& Trading & 3 & 3 \\
\hline & Waste disposal site & 1 & 20 \\
\hline yes & Gas Station & 5 & 3 \\
& Industry & 1 & 1
\end{tabular}

Figure 9. Reused sites, type of polluting activity and the current classification.

Figure 9 shows information regarding reused and polluting activity also looking to current site classification, according to the São Paulo Environmental Agency[21] and considering just two grades, contaminated areas with confirmed risk and remediated places for declared use. There are 6 places with a different current use (reused), however, still classified with confirmed risk for human health.

\section{1. District of Santo Amaro}

Santo Amaro, according to Table 3, is the most contaminated district. Although this result was expected, because Santo Amaro is a historic industrial district. Also, it has the most percentage of clean-up areas. Currently the district, according to the zoning law [50], is a well-diversified place, and has two large areas. First a predominantly residential area and a second which mixed areas: territories of transformation whose objective is the constructive density, population and economic activities and public services, areas of economic development, aiming at the maintenance of existing non-residential uses. Figure 10 shows the distribution of the contaminated areas on the district.

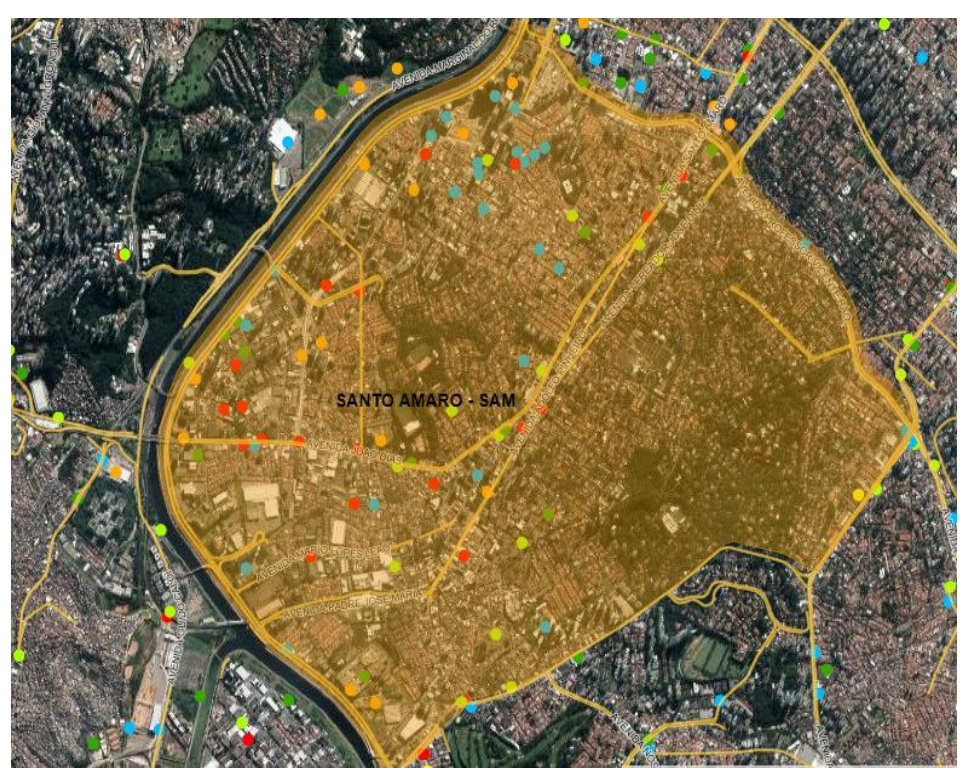

Figure 10. Contaminated land in Santo Amaro.

Through figure 10 the residential zone and the mixed zone of the district of São Amaro are readily distinguishable. Contaminated and remediated areas are predominantly located on the left side of the image, while the residential area is located to the right. Given the mixed district character, is understandable the data referring to population density, of 4,317.60 inhabitants/km2 the second lowest of the studied districts. It is also important to note how this district is transforming. Of the 80 contaminated areas present in the district, 33 are from industries, while 42 are gas stations. This relationship between the number of areas coming from industries and gas stations is significantly 
different from the data identified in the city of São Paulo and looking at the data set of the 05 districts evaluated.

\section{2. District of Butantã}

District of Butantã has the second-best relation between the contaminated land number and the percentage of remediated areas. It has predominantly residential and commercial areas[50]. It is where the University of São Paulo located. Of the 26 contaminated areas, four has confirmed risk; this means $15 \%$ of the total. The district follows the trend of the city; the origin of the contaminated areas are essentially gas stations.

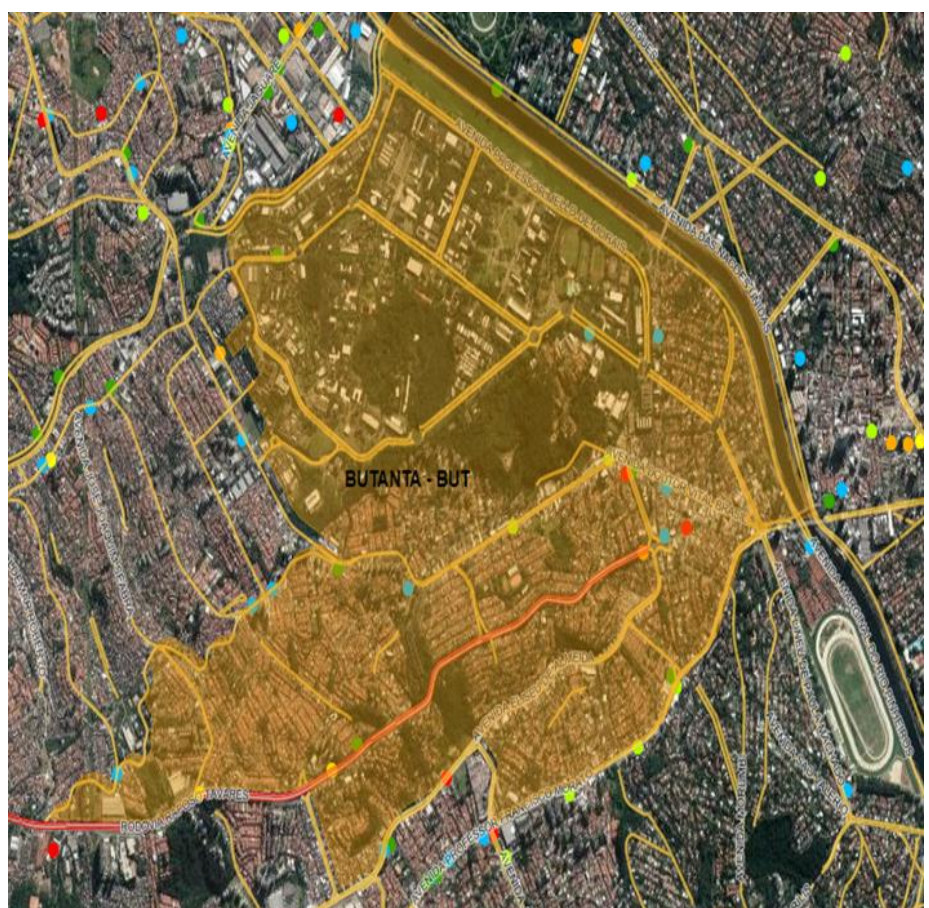

Figure 11. Contaminated land in Butantã.

\section{3. District of Cambuci}

The Cambuci district is in second place in the number of contaminated areas. According to table 3, there are 26 areas. However, it has the lowest percentage of remediated areas in all evaluated districts, $21.43 \%$. It is one of the oldest districts of the city of São Paulo and has an industrial tradition. Nowadays, it has a zone of qualification territory (maintenance of existing nonresidential uses, promotion of productive activities and diversification of uses) and transformation territories (promotion of population density, economic activities, and public services)[50]. Unlike the trend of the city of São Paulo and the results of another historically industrial district, Santo Amaro, in Cambuci the number of contaminated areas from industrial activity is higher than by gas stations. There are 12 areas derived from gas station for 14 to industries. Figure 12 illustrates the district and the contaminated areas.

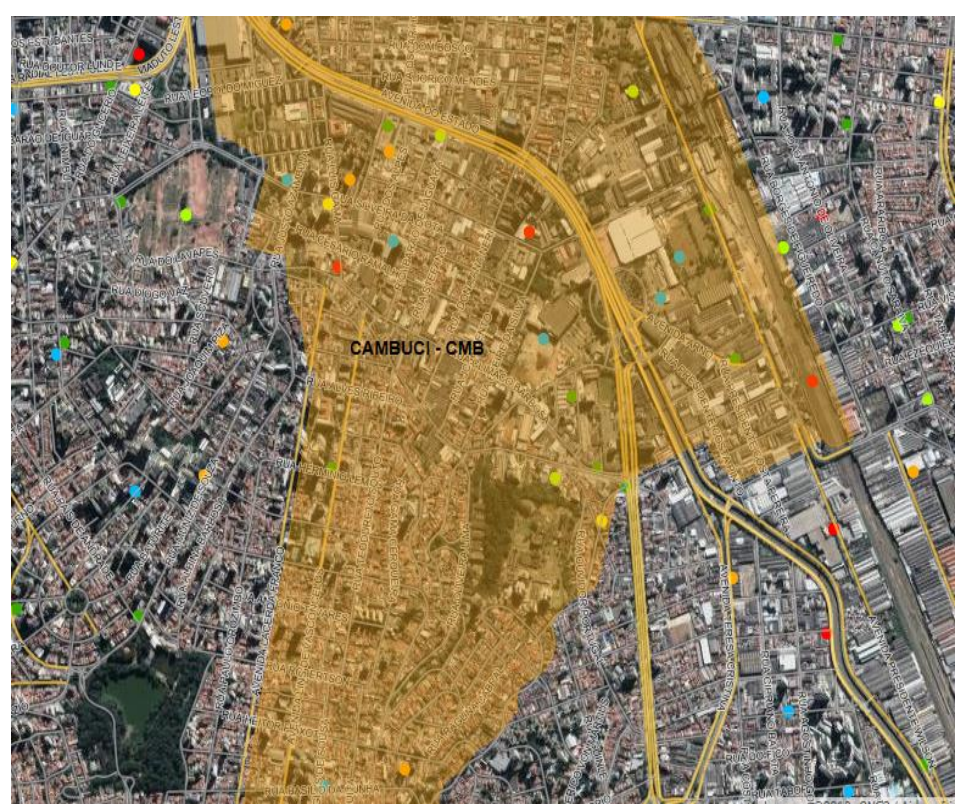

Figure 12. Contaminated land in Cambuci.

\section{4. District of Casa Verde}

Casa Verde district is the second in population density, $12,113.94$ inhabitants $/ \mathrm{km}^{2}$. It is a mixed district, with predominantly residential areas, although most are composed of mixed zones and central zones, where diversification of uses or moderate population density is sought[50]. It follows the reality of the city, in which the primary cause of the contamination is gas stations, in 15 places. Relevant information identified in the analysis of this district is that all areas reused, three places, are classified as remedied areas, it means, the whole remediated process was finalized.

\section{5. District of Aricanduva}

The district Aricanduva is the most densely populated 13,106.21 inhabitants $/ \mathrm{km}^{2}$ and has the lowest price per square meter of the districts evaluated. It is a necessarily mixed district, including predominantly industrial areas and spaces where purpose is population density, economic activities, and public services. Also aims to maintain non-residential uses and foster productive activities[50]. As the Casa Verde district has all the reused areas remediated, 4 areas, means $25 \%$ of the total contaminated areas identified in the region. Gas stations are also the most significantly responsible for contaminated in this district, with 11 places. In this 
district, of the 16 identified areas, 10 are in the process of clean up or monitoring to evaluate the efficiency of the remediation process. Figure 13 exhibit the district and the contaminated areas.

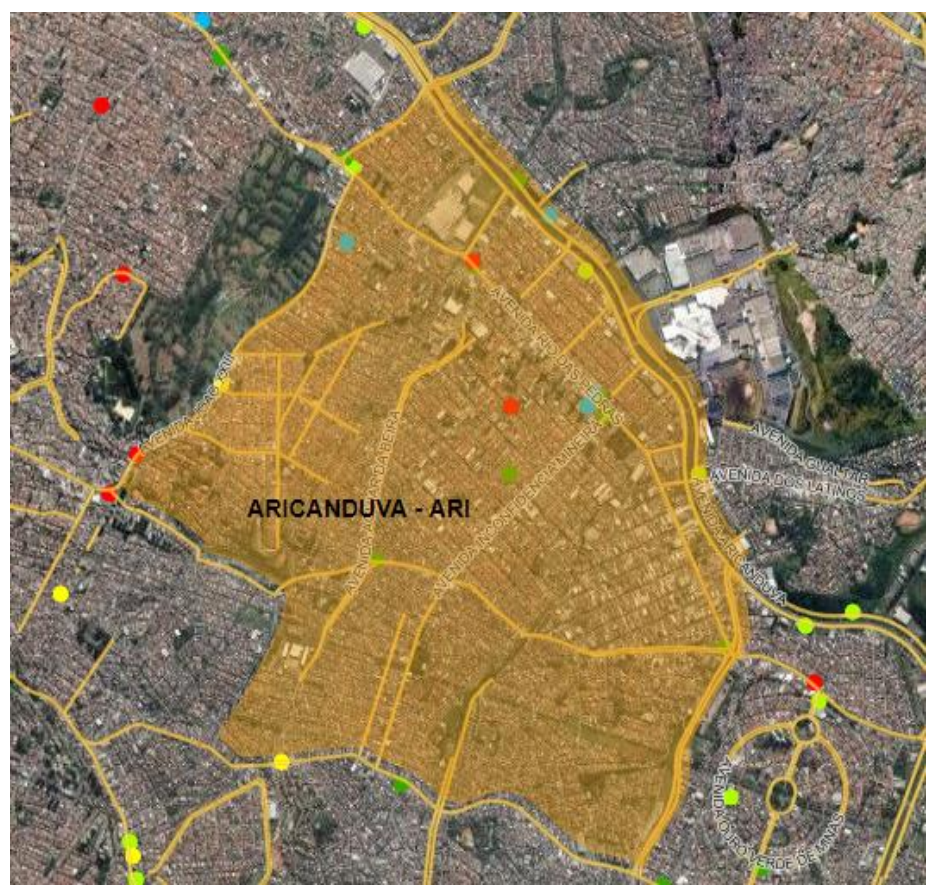

Figure 13. Contaminated land in Aricanduva.

\section{Conclusion}

According to the information found, the process of revitalization and clean-up is happening in all evaluated districts, however in Santo Amaro the process is more evident. It is the same place where the price of the square meter is the most expensive and it had the highest percentage of contaminated areas with confirmed risk. Nevertheless, the dynamic of revitalization process is different around the district, and this is expected, considering the essential factors of each district, as localization and the zoning law, how it can also be observed in this research. The data also showed that environment compartment more affected is Groundwater. The existence of many areas contaminated can impair the use of groundwater to supply public.

Recognize the reality of the city is quite important to create comprehensive public policy. Local studies are essential because, in a huge city as São Paulo, the districts can present different realities, originated on owner place history of land use and occupation, like Santo Amaro and Cambuci, two typical industrial districts, evaluated in this research. This difference means different answers on public strategies to the revitalization of contaminated sites. It is necessary to consider and to understand aspects, as which places need more control in the revitalization process to ensure that the project of cleanup can be completed or what districts have more contaminated land with confirmed risk and how can this affect the public health. To build a Sustainable city that can organize, optimize own space, and offer safety to inhabitants it is necessarily to use the available data about contaminated land and to create analysis to support, as local studies, for offering more instruments to policymakers.

\section{Acknowledgements}

Juliana dos Santos Lino acknowledges Nuclear and Energy Research Institute, IPEN-CNEN/SP, for providing facilities, and research funding to carry out the study.

\section{References}

[1] United Nations, "The World's Cities in 2016: Data Booklet.," 2016.

[2] W. Commission on Environment, "Report of the World Commission on Environment and Development: Our Common Future Towards Sustainable Development 2. Part II. Common Challenges Population and Human Resources 4."

[3] United Nations, "United Nations Conference on Sustainable Development, Rio+20 ... Sustainable Development Knowledge Platform," 2012. [Online]. Available: https://sustainabledevelopment.un.org/rio20. [Accessed: 11-Mar-2019].

[4] United Nations, "Transforming our world: the 2030 Agenda for Sustainable Development," New York, Feb. 2015.

[5] J. B. Silkworth, D. N. McMartin, R. Rej, R. S. Narang, V. B. Stein, R. G. Briggs, L. S. Kaminsky, "Subchronic Exposure of Mice to Love Canal Soil Contaminants," Fundam. Appl. Toxicol., 1984.

[6] U. S. E. P. A. USEPA, “Contaminated Land,” 2018. [Online]. Available: https://www.epa.gov/reportenvironment/contaminated-land. [Accessed: 11Mar-2019].

[7] Congress of the United States of America, Public Law 107-118 - Small Business Liability Relief and Brownfields Revitalization Act. 2002, pp. 1-27.

[8] United Nations, "The Sustainable Development Goals Report 2017," New York, 2017.

[9] United Nations, "Cities - United Nations Sustainable Development Action 2015," 2015. 
[Online].

Available: https://www.un.org/sustainabledevelopment/ci ties/. [Accessed: 11-Mar-2019].

[10] A. L. S. Spinola and A. Philippi, "Contaminated Sites and Public Policies in Sao Paulo State, Brazil," in Environmental Management in Practice, Elzbieta Broniewicz, Ed. InTech, 2011, pp. 145158.

[11] Brasil, Constituição da República Federativa do Brasil de 1988. Brasil, 1988.

[12] 0. Brilhante and R. Franco, "Avaliação da contaminação e identificação das rotas ambientais de exposição ao $\mathrm{HCH}$, ao DDT e aos metais na Cidade dos Meninos, Amapá, Figueiras e Pilar, área metropolitana do Rio de Janeiro," Cad. Saúde Coletiva, vol. 15, no. 1, pp. 55-78, 2007.

[13] C. E. Teixeira, F. G. Motta, and S. L. de Moraes, Panorama GAC: mapeamento da cadeia de gerenciamento de áreas contaminadas, 1st ed. São Paulo: IPT, 2016.

[14] Brasil, "Resolução do Conselho Nacional de Meio Ambiente no 420," Diário Of. da União no 249, vol. 2013, pp. 81-84, 2009.

[15] J. dos S. Lino and A. R. Aquino, "Proposta de Classificação de Brownfields," OLAM - Ciência Tecnol., vol. 1, no. 1, pp. 1-23, 2017.

[16] A. Luiza Silva Spínola, A. Philippi, and S. Tomerius, "Contaminated sites and brownfield management," Manag. Environ. Qual. An Int. J., vol. 21, no. 3, pp. 299-307, Apr. 2010.

[17] C. A. do E. de S. P. CETESB, "Manual de Gerenciamento de Áreas Contaminadas Projeto CETESB - GTZ Cooperação Técnica Brasil Alemanha," no. 2ed, p. 389, 2001.

[18] A. Marker, Manual: Revitalização de áreas degradadas e contaminadas (brownfields) na América Latina, ICLEI - Go. São Paulo, 2013.

[19] São Paulo, Lei no 13.577, de 08 de julho de 2009 Assembleia Legislativa do Estado de São Paulo. 2009.

[20] São Paulo State, Decreto n.59.263, de 05 de junho de 2013. 2013.

[21] Companhia Ambiental do Estado de São Paulo [CETESB], "Relação das áreas contaminadas e reabilitadas no estado de São Paulo 2017," São Paulo, 2017.

[22] São Paulo City, Lei $n^{\circ}$ 16.050, de 31 de julho de 2014. 2014.

[23] T. B. Silva, "Áreas de abandono Análise com base nos fundamentos do desenho ambiental sobre projetos que visam a recuperação de territórios degradados," Rev. LABVERDE, vol. 11, no. 04, pp. 76-102, 2016.

[24] Instituto Brasileiro de Geografia e Estatistica, "IBGE | Brasil em Síntese | São Paulo | São Paulo | Panorama," 2017. [Online]. Available: https://cidades.ibge.gov.br/brasil/sp/saopaulo/panorama. [Accessed: 14-May-2018].

[25] A. M. G. Figueiredo, M. Tocchini, and T. F. S. dos Santos, "Metals in playground soils of São Paulo city, Brazil," Procedia Environ. Sci., vol. 4, pp. 303309, 2011.

[26] V. C. F. Salinas, "Brownfields and its consequences: A particular case of the urban operation of Tamanduateí districts," Rev. LABVERDE, vol. 11, no. 03, pp. 52-74, 2016.

[27] M. Barbosa, R. A. Bertolo, and R. Hirata, "A Method for Environmental Data Management Applied to Megasites in the State of Sao Paulo, Brazil," J. Water Resour. Prot., vol. 9, pp. 322-338, 2017.

[28] Companhia Ambiental do Estado de São [CETESB], "Texto explicativo Relação das áreas contaminadas e reabilitadas no Estado de Sâo Paulo," São Paulo, 2017.

[29] Fundação Sistema Estadual de Análise de Dados [SEADE], "Portal de Estatísticas do Estado de São Paulo: Perfil dos Municípios Paulistas," 2018. [Online]. Available: http://www.perfil.seade.gov.br/\#. [Accessed: 14May-2018].

[30] Prefeitura de São Paulo, "Dados demográficos dos distritos pertencentes às Prefeituras Regionais | Secretaria Municipal de Prefeituras Regionais | Prefeitura da Cidade de São Paulo," 2017. [Online]. Available: http://www.prefeitura.sp.gov.br/cidade/secreta rias/regionais/subprefeituras/dados_demografi cos/index.php?p=12758. [Accessed: 14-May2018].

[31] Fundação Instituto de Pesquisas Econônimcas [FIPE] and ZAP Imoveis, "Mercado Imobiliário | Preços de Imóveis, Apartamentos e Casas | Índice FIPE ZAP Imóveis." [Online]. Available: http://www.zap.com.br/imoveis/fipe-zap/.

[Accessed: 14-May-2018].

[32] Prefeitura de São Paulo, "Sistema de Consulta do Mapa Digital da Cidade de São Paulo," 2018. [Online]. Available: http://geosampa.prefeitura.sp.gov.br/PaginasPu blicas/_SBC.aspx\#. [Accessed: 20-May-2018]. 
[33] Governo do Estado de São Paulo, "DataGeo Sistema Ambiental Paulista," 2018. [Online]. Available:

http://datageo.ambiente.sp.gov.br/coffey?_48_I

NSTANCE_KDzpt1cNV1RS_iframe_text=areas+co ntaminadas\&enviar $=$ Consultar\&p_p_id=48_INST ANCE_KDzpt1cNV1RS\&_48_INSTANCE_KDzpt1c NV1RS_iframe_avancado=false\#_48_INSTANCE_ KDzpt1cNV1RS_\%3Dhttp\%253A\%252F\%252Fd atageo.ambi. [Accessed: 21-May-2018].

[34] M. Habermann and N. Gouveia, "Requalificação urbana em áreas contaminadas na cidade de São Paulo," Estud. Avançados, vol. 28, no. 82, pp. 129137, 2014.

[35] J. dos S. Lino and A. R. de Aquino, "Análise da Evolução das áreas contaminadas no município de São Paulo," in Anais - Congresso Brasileiro de Gestão Ambiental, 2017, pp. 1-7.

[36] M. Majone et al., "In situ groundwater and sediment bioremediation: barriers and perspectives at European contaminated sites," $N$. Biotechnol., vol. 32, no. 1, pp. 133-146, Jan. 2015.

[37] P. Li, R. Tian, C. Xue, and J. Wu, "Progress, opportunities, and key fields for groundwater quality research under the impacts of human activities in China with a special focus on western China," Environ. Sci. Pollut. Res., vol. 24, no. 15, pp. 13224-13234, May 2017.

[38] K. Sam, F. Coulon, and G. Prpich, "A multi-attribute methodology for the prioritisation of oil contaminated sites in the Niger Delta," Sci. Total Environ., vol. 579, pp. 1323-1332, Feb. 2017.

[39] F. Coulon et al., "China's soil and groundwater management challenges: Lessons from the UK's experience and opportunities for China," Environ. Int., vol. 91, pp. 196-200, May 2016.

[40] F. G. Piga et al., "Multi-criteria potential groundwater contamination and human activities: Araras watershed, Brazil," RBRH, vol. 22, no. 0, Oct. 2017.

[41] Companhia Ambiental do Estado de São Paulo [CETESB], “Águas Subterrâneas - Sistema
Ambiental Paulista - Governo do Estado de São Paulo," $2018 . \quad$ [Online]. Available: http://cetesb.sp.gov.br/aguas-subterraneas/.

[Accessed: 21-May-2018].

[42] R. Bertolo, R. Hirata, B. Conicelli, M. Simonato, A. Pinhatti, and A. Fernandes, "Água subterrânea para abastecimento público na Região Metropolitana de São Paulo: é possível utilizá-la em larga escala?," Rev. DAE, vol. 63, no. 199, pp. 617, 2015.

[43] L. Pizzol et al., "Timbre Brownfield Prioritization Tool to support effective brownfield regeneration," J. Environ. Manage., vol. 166, pp. 178-192, 2016.

[44] U. S. E. A. USEPA, “A Citizen's Guide to Excavation of Contaminated Soil What Is the Excavation of Contaminated Soil?," 2012.

[45] U. S. E. P. A. USEPA, "Elements for Effective Elements for Effective Management of Management of Operating Pump and Operating Pump and Treat Systems Treat Systems," Cincinnati.

[46] E. de M. Marques and J. A. T. Guerra, "Solos Contaminados por Hidrocarbonetos de Petróleo," in Simpósio Nacional de Geomorfologia - SINAGEO, 2018, pp. 1-13.

[47] U. S. E. P. E. USEPA, “A Citizen's Guide to In Situ Chemical Oxidation What Is In Situ Chemical Oxidation?," 2012.

[48] U. S. E. P. A. USEPA, "CLU-IN | Technologies Remediation: Soil Vapor Extraction Overview," 2018. [Online]. Available: https://cluin.org/techfocus/default.focus/sec/Soil_Vapor_E xtraction/cat/Overview/. [Accessed: 11-Mar2019].

[49] U. S. E. P. A. USEPA, "Monitored Natural Attenuation of Chlorinated Solvents," Washington, 1999.

[50] Prefeitura de São Paulo, Lei no16.402, de 22 de março de 2016. Brazil: Imprensa oficial do estado, 2016, p. 177. 